\title{
高温で計測可能な光ファイバ超音波センサの構築
}

于 豊銘 ${ }^{* 1}$ ，岡部 洋二*2

\section{Optical fiber sensor for ultrasonic detection at high temperature}

\author{
Fengming $\mathrm{YU}^{* 1}$ and Yoji OKABE ${ }^{* 2}$ \\ ${ }^{*}{ }_{1,2}^{* 2}$ The University of Tokyo, Institute of Industrial Science \\ 4-6-1 Komaba, Meguro-ku, Tokyo 153-8505, Japan
}

\section{Received: 9 September 2017; Revised: 1 November 2017; Accepted: 7 December 2017}

\begin{abstract}
Because of the stable material property of optical fiber up to $1000^{\circ} \mathrm{C}$, fiber-optic Bragg grating (FBG) sensor is considered as one of possible ultrasonic sensors used at ultrahigh temperature. However, disappearance of reflectivity of a normal FBG in the high temperature above $900^{\circ} \mathrm{C}$ makes the ultrasonic detection impossible. In order to detect ultrasonic wave under high temperature environments, we conducted an anneal heat treatment to produce a regenerated fiber Bragg grating (RFBG) sensor. Because the RFBG has a stable reflectivity even at temperature of $1000^{\circ} \mathrm{C}$, we detected the ultrasonic wave successfully at the temperature. Especially, because a $\pi$-phase-shifted FBG (PSFBG) was used as the seed grating, the RFBG sensor possessed very short effective gauge length that resulted in a broad bandwidth response to ultrasonic wave over $1 \mathrm{MHz}$. Hence, we believe that the ultrasonic RFBG sensors could be potentially applied for ultrasonic detection in non-destructive tests to evaluate microscopic damage in materials under extreme high-temperature environment.
\end{abstract}

Keywords : Regenerated fiber Bragg grating, High tempeture, Ultrasonic detection, Non-destructive test, Composite materials

\section{1. 緒言}

近年，エンジンのエネルギー変換効率の更なる向上を図るため，耐熱性に優れた軽量なセラミックス基複合材 料 (Ceramic matrix composites: CMCs) の適用が期待されている（Padture, 2016). CMC は，母材のき裂をはじめ とした，極めて微視的かつ複雑な損傷が累積発生することで破壊につながる．そのため，航空機エンジン用材料 としての安全性を確保するためには, 1000 度を超える実環境下においてそれらの損傷発生過程を観察する必要が あり，そのための非破壊検查技術の構築が望まれている。その高温場で適用可能な非破壊検查法の一つとして超 音波の利用が挙げられる(井原, 2015). 一般的には超音波送受信に圧電セラミックス PZT 素子が用いられている. しかし，汎用のPZT センサはセンシング可能な上限温度が限られ，高温場での使用が困難である． $1000^{\circ} \mathrm{C}$ 耐熱 性を有寸る特殊 PZT センサの研究開発が進んでいるが（Johnson et al., 2013; Kirk et al., 2007)，しかし，圧電性の 結晶は温度の変化に依存した感度の低下や，周波数帯域の制限といった問題がある.さらに，高温環境下での耐 久性に優れる電極と, その電極と PZT との結合方法など, センサの実用化における課題も残っている (Jiang et al., 2013).

その一方で, 光ファイバは石英ガラス製で耐熱性に優れるため（長，伊藤，2015）, 光ファイバセンサの一種で ある Fiber Bragg grating (FBG)センサを高温用センサに適用することが期待できる. 汎用の Type I の FBG は，ゲル

No.17-00406 [DOI:10.1299/transjsme.17-00406], J-STAGE Advance Publication date : 15 December, 2017

*1 東京大学 生産技術研究所（广153-8505 東京都目黒区駒場 4-6-1)

*2 正員, 東京大学 生産技術研究所

E-mail of corresponding author: houmei@iiis.u-tokyo.ac.jp 
マニウム添加石英ガラス製光ファイバ（H-loaded germanosilicate fiber）のコアに紫外線を照射することによって作 製される，その UV 照射によるガラス屈折率変調の微視的なメカニズムはまだ解明されていない（Hill, 1997; Kashyap, 1999)が, ガラス結晶においては酸素欠乏ゲルマニウムセンタ (Germanium-oxygen-deficient center: GODC) をはじめとする電子的欠陥が生成することによって，ガラスの屈折率が変化するという仮説で解釈されている （Hill, 1997; Starodubov et al., 1997），しかしながら，熱エネルギーによってそれらの欠陌が変化し，屈折率が変化 することで, Type I の FBG が消失することが知られている，そこで，FBG センサを高温環境に設置して超音波を 計測するためには土夫が必要となる.

近年では, Type-I の FBG に対して, $900{ }^{\circ} \mathrm{C}$ 以上の高温でアニーリング処理を行うことで, 一度消失した FBG を再生させることが可能になると報告されている（Fokine, 2002）。このアニーリング処理によって得られた FBG は再生 FBG（Regenerated FBG: RFBG）と呼ばれる. そして, RFBGセンサは, 再び $1000{ }^{\circ} \mathrm{C}$ まで加熱しても消 失せず，つまり，耐熱性に優れることが分かっている.

Fokine（Fokine, 2002）は，アニーリング処理中では FBG を形成している石英ガラスが，加熱時に熱平衡状態 に移る際に起こる化学反応によってRFBGが形成すると仮定していた，一方， Canning （Canning, 2016）は，ア ニーリング処理は UV 照射により生じた, FBG のクラッド-コア界面における残留応力の周期的変動を安定化させ た結果，その再構成された応力分布はあらためてガラスの屈折率を変調させることで，新たな周期的グレーティ ング，すなわち RFBG が形成するという，力学的な形成メカニズムを主張してきた．これらの RFBG に関する解 説に基づき, 数多くの研究で, 再生プロセスを改良し（Bandyopadhyay et al., 2011; Zhang et al., 2007), そして各種 光ファイバにおいて再生グレーティングを形成することが実現できている（Bandyopadhyay et al., 2008; Bueno et al., 2013; Yang et al., 2014). 特に, 新規ガラス材料により作られた光ファイバにおいて, $1400^{\circ} \mathrm{C}$ ま字安定した性 質を有する RFBG を形成できることが報告されている. (Yang et al., 2014)

それらの基礎研究に基づき, RFBG センシングシステムは, 極限環境下における温度と静的ひずみの計測 (Wang et al., 2013), 高温液体の流量計測(Chen et al., 2014), さらに石英ガラス製光ファイバの粘弾性評価(Shao et al., 2013) を実現することができている. しかし，著者らの知る限り，RFBG センサを用いて超音波を計測した前例がない.

そこで, 本研究では, 超音波計測に高温用 RFBGセンサを適用することを試みる. 第 2 章では, 高性能な位相 シフト FBG (PSFBG) センサに対して, アニーリング処理を行うことによる RFBG センサの形成プロセスを述べ る. その後, その RFBG の耐熱性を検証する. 第 3 章では, その RFBG センサを用いて, $1000^{\circ} \mathrm{C}$ 高温環境下に おける超音波計測を実現可能なセンシングシステムを構築する，そして，その高温用超音波センサのセンシング 特性を調べる.

\section{2. アニーリング処理による RFBG の形成}

本研究で用いる PSFBG は，FBG における周期的に変化した屈折率の中心に って形成されたものである. その位相のズレによって, 本来の FBG の透過光スペクトルの中央において, 帯域幅 の狭い, 急峻なピークを有する (図 3 を参照)。このピークを利用することによって, PSFBG センサは高感度で 超音波を計測できることが先行研究で確認された(Wu and Okabe, 2012). また，通常の FBG で超音波を正確に受 信するためには, グレーティング全体が伸び縮みしなければならない. そのため, 超音波センサ長はFBGのグレ 一ティング長と等しく,それより短い波長を持つ超音波を計測することが困難である.これに対して, PSFBG は, $\pi$ 位相シフト点の近傍でのひずみに対して応答するため, その有効センサゲージ長は $0.5 \mathrm{~mm}$ 以下で極めて短い (Rosenthal et al., 2011). そのため, 短波長, 寸なわち高周波数までの広帯域にわたる超音波を受信可能である. 本研究では, この高感度かつ広帯域性を持つ PSFBG センサを利用して RFBG センサを形成することで, 高性能 な高温用超音波センサを構築することを試みる.

アニーリング処理は，管状高温炉で実施した，処理中における RFBG の形成過程を観察するため，温度変化の 時間履歴に伴う PSFBG センサの反射率のピーク值の変化を光スペクトラムアナライザ (Anritsu, MS9710C) で計 測した（図 1 (a)).この結果より， $600^{\circ} \mathrm{C}$ 以上になると, PSFBG の反射率が急劇に低下していることが分かる. そして, $900^{\circ} \mathrm{C}$ 付近では PSFBG は完全に消失している. そこで, RFBG の形成トリガ温度でアニーリングを実施 寸る. 光ファイバの材質に依存してトリガ温度は異なるが, 本研究で用いられているゲルマニウム添加石英ガラ 
ス製光ファイバのトリガ温度は $920^{\circ} \mathrm{C}$ (Laffont et al., 2013b)である. その温度を上げて保持すると, 消失した PSFBG の反射率が徐々に復活してくることが分かる．さらに，そのまま約 30 分保持すると，反射率が- $12.28 \mathrm{~dB}$ まで戻 り，その後は一定值を保っていた。 つまり，RFBGの形成が終了したと考えられる.

アニーリング処理の後, RFBG の而熱性を検証するため, 再び室温から $1100^{\circ} \mathrm{C} の$ 高温まで加熱しながら, RFBG の反射率の変化を観察した. その結果 (図 1 (b)), 温度は $1000^{\circ} \mathrm{C}$ ま早すると, RFBG の反射率は常温時の-11.4 $\mathrm{dB}$ から-15.9〜17.9 dB に低下した. しかしながら, PSFBG のように消失することがなかったため, RFBG は $1000^{\circ} \mathrm{C}$ 以上の耐熱性を有することが分かった.
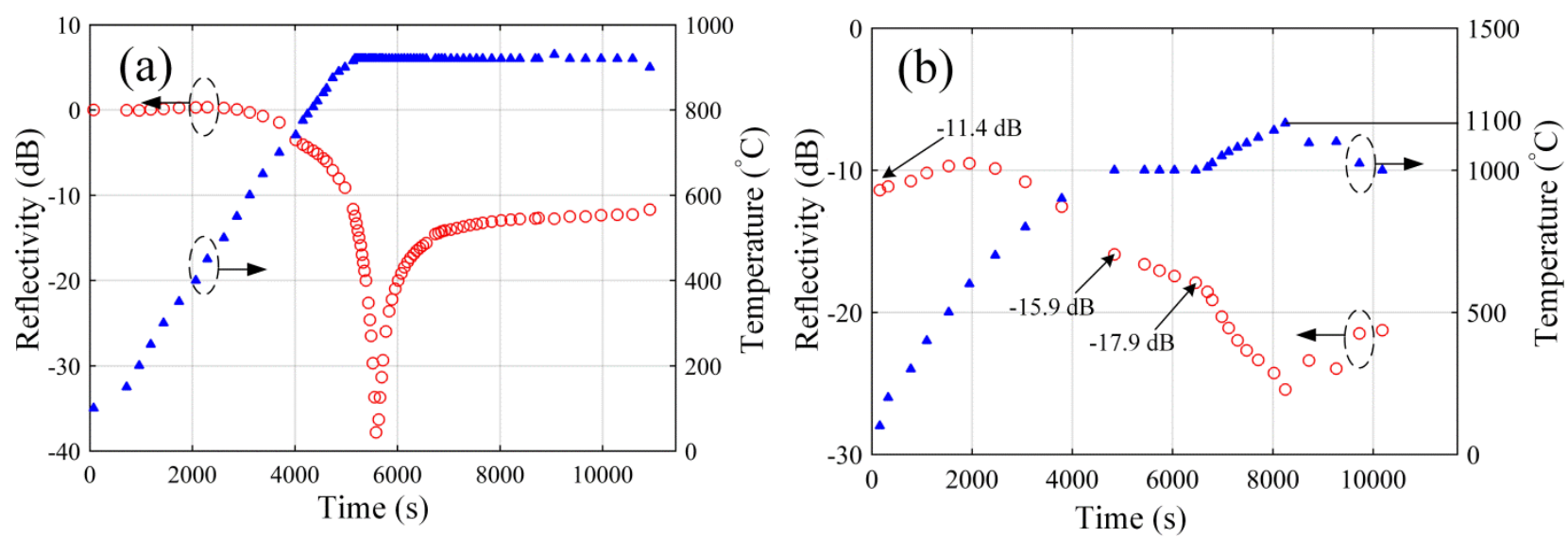

Fig. 1 (a) Temperature history of the annealing process and peak reflection during Bragg grating regeneration. (b) Reflection intensity of the RFBG during reheating.

しかし,アニーリング処理後には, 光ファイバはガラス素線となり, 機械的に破断しやすい状態になっている. 実応用のためには再被覆を実施しなければならない，その際，被覆のコストと加工しや寸さを配慮し，適用温度 範囲に応じて被覆材を選択する必要がある. 例えば, $400^{\circ} \mathrm{C}$ ま゙の温度条件で RFBG センサを適用する場合には, 通常のポリイミド樹脂被覆でも十分である. 温度が $400^{\circ} \mathrm{C} \sim 800^{\circ} \mathrm{C}$ に上昇すると，カーボン粒子あるいはカーボン 繊維を用いた光ファイバの被覆（本庶，赤坂，1994）が適用できる，さらなる高温場では，ニッケル，銀または 金などの金属被覆を利用することが考えられる，但し，今までの RFBG に関する研究では，適切な再被覆アプロ 一チに関する研究が少ないことに加え, 而熱被覆と光ファイバとの結合状態も RFBG センサによる超音波計測に 影響する．今後，再被覆に関する検討を行う必要があるが，まず，RFBG センサは超音波センサとして有効であ るかどうかを検証することが重要であるため, 本研究では, 光ファイバがガラス素線状態のままで, 超音波計測 実験を実施する。

\section{3. 高温用 RFBG 超音波センシングシステムの構築}

\section{$3 \cdot 1 \quad \mathrm{RFBG}$ 超音波センシングシステムの構成}

RFBG の耐熱性を利用し, 高温環境における超音波を計測可能なセンシングシステムを構築することを試みる. FBG 系の超音波センサは，波動が伝播する際に生じた動的ひずみに応答する．そのひずみの変動に対して，FBG の Bragg 波長（FBG からの反射光の主な波長成分）は線形にシフトする.このため, Bragg 波長のシフト量を高 速で計測できれば，超音波に伴うひずみの動的な変化を推定することができる．しかし，その FBG の反射光スペ クトルの変化は, 直接高速で観察することが難しい. そのため, Bragg 波長のシフト量を光フィルターで光パワ 一の変化に変換して, さらに電圧信号に復調する必要がある. 


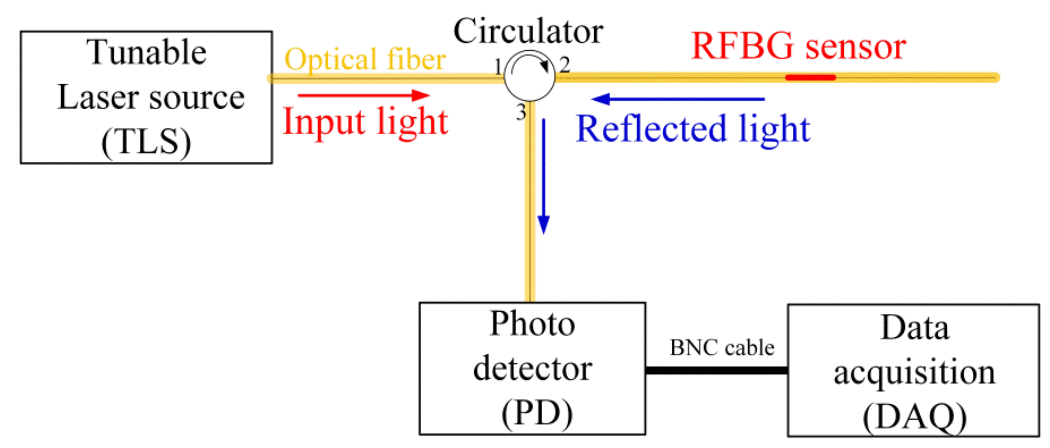

Fig. 2 Schematic diagram of the RFBG sensing systems.

本研究では, Edging Filter 法（Daniel et al., 2003）という復調方法に基づき, 図 2 に示すセンシングシステムを 構築した. この超音波検知システムでは RFBG をセンサとして用いる. システムの光源には波長可変レーザ (TLS, Agilent, 81682A）を用いる. 特に，このシステムでのレーザ光は，Bragg 波長のシフト量を定量的に検知するた めの光フィルターでもある. RFBG の反射帯域幅と比心゙，レーザは単一周波数の光を出力するため，波長域では ほぼ線状である. そこで，レーザ光の波長を RFBG のスペクトルのエッジ (ピーク斜面の線形領域, 図 3 を参照) に合わせれば，ひずみの変化により生じた，RFBG のスペクトルのシフト量を，反射光パワーの変化としてとら えることが可能となる．RFBG センサはサーキュレータを通じてレーザ光源と接続する．さらに，RFBGからの 反射光はそのサーキュレータによって, 光信号を電圧信号に変換するためのフォトディテクタ (New Focus, 2117) に届く。このシステムを用いることで復調した，超音波の動的なひずみに対応する電圧信号はデータ収集機器に より記録・保存される.

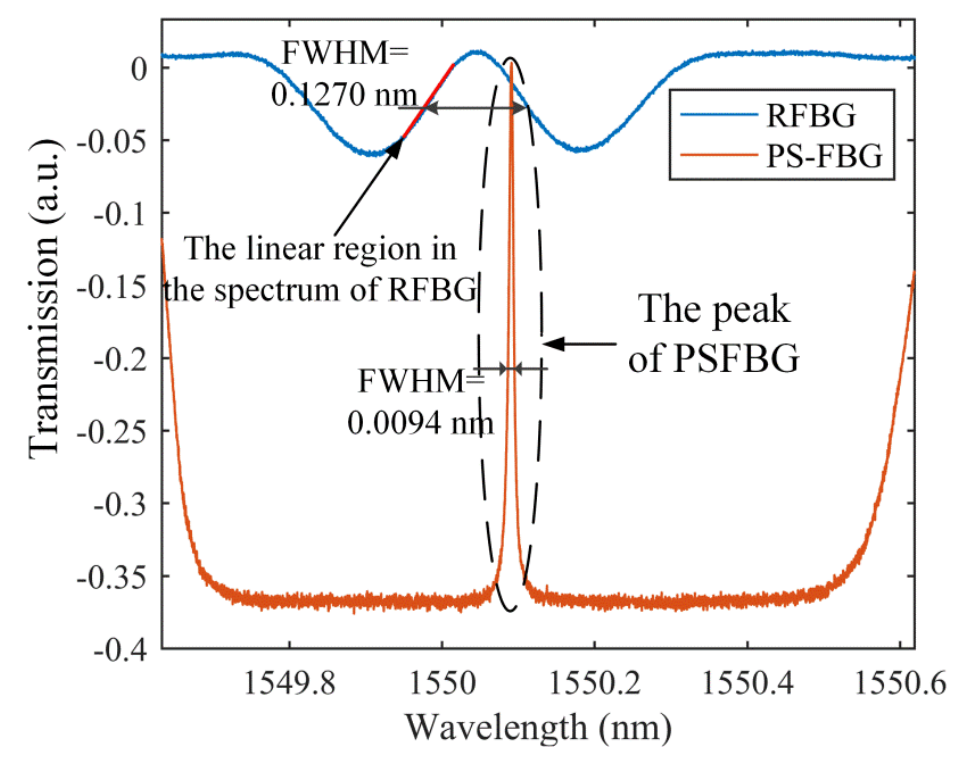

Fig. 3 Spectra of the RFBG and PSFBG measured by sweeping the TLS.

以上のシステムにおいて，RFBG の反射光スペクトルにおけるエッジの条件は，超音波計測の感度に大きく影 響する，そこで，アニーリング処理後に，高温炉の温度が室温まで下がってから，RFBG の反射光スペクトルを レーザ掃引で観察した．PSFBG センサの感度と比較するために，ほぼ同じ計測条件で得られた PSFBG と RFBG のスペクトルを図 3 に示寸.このグラフより, PSFBG から形成した RFBG の透過光スペクトルにおける中央ピー クは，元の PSFBG のピークと比較すると，かなり緩やかになっていることが分かる．この現象は，アニーリン グ処理でコアとクラッドとの界面におけるひずみを再構成する（Canning, 2016）際に，本来のUV 照射で生じさ せた $\pi$ の位相が, RFBG 形成中に異なる角度に変化させられたためと考えられる. その位相が変化した結果, RFBG 
のスペクトルにおけるエッジの傾き（赤線で示したエッジ部分の傾きは $0.76 \mathrm{~nm}^{-1}$ ) は, PSFBGのもの $\left(87 \mathrm{~nm}^{-1}\right)$ と比べてかなり小さくなっている。このエッジの傾きが大きければ大きいほどセンシング感度が良いため, RFBG センサは PSFBG センサより感度が低下していると考えられる。しかし，同じゲージ長を持つ普通の FBG センサはエッジ部分の傾きが $0.48 \mathrm{~nm}^{-1}$ であるため(Wu and Okabe, 2012), PSFBG から形成した RFBG センサは通 常の FBG センサより感度が良いと考えられる.

\section{3-2 RFBG センサによる高温での超音波計測}

次に，図 4(a) に示す実験セットアップで超音波計測の検証実験を行う. 実用時には, RFBGセンサを，高温環 境下における構造物に接着する必要がある.しかし, 高温環境下での構造物を伝播する超音波の分散性変化等の 諸特性はまだ十分解明されていない. そのため, 温度の変化によって計測結果が変化した場合, その変化は RFBG センサの温度変化により生じたのか, もしくは構造材料を伝わる超音波の分散性が温度で変化することにより生 じたのかを判明することが困難である，そこで本研究では，図 4(a)に示すように光ファイバを高温炉から引き出 し，常温環境下に設置したアルミ板 $\left(200 \times 200 \times 3 \mathrm{~mm}^{3}\right)$ に接着して，RFBG センサ部は高温環境下に設置し た状態で, フィルム状の圧電アクチュエータである, マクロファイバーコンポジット (MFC) で励起してアルミ 板を伝播した超音波を計測した。ただし，アクチュエータと接着点との距離を $100 \mathrm{~mm} に$ に RFBGと接着との 距離を $300 \mathrm{~mm}$ にした. 光ファイバは耐熱性に優れるため, $1000^{\circ} \mathrm{C}$ 上の高温環境下でも比較的安定した力学特 性を保てる. さらに，著者らの先行研究（Yu et al., 2016）では，糸状の光ファイバ（直径 : $125 \mu \mathrm{m} ）$ は FBG 系センサにとって, 理想的な超音波ウェーブガイドであるため, 遠隔で設置されたセンサは接着点におけるラム 波モードの挙動をそのまま計測することが分かっている.この理由として, 図 4(b)に示すように, 光ファイバ・ ウェーブガイドは極めて細いため，広帯域にわたって基本縦波モードと基本横波モードの夕が存在する. これに 加え, 光ファイバ内に生じる軸方向ひずみ成分は, 中心軸上では縦波モードによる成分のみが存在することにな る. すなわち, 光ファイバの中心軸（直径： $0.01 \mathrm{~mm}$ ）にある RFBG センサによって受信されるのは，光ファイ バを伝わる基本縦波モードのみとなる.ここではアルミ板中のラム波を計測するので，その波長のオ一ダーは数 ミリ〜数センチ程度であり，光ファイバの直径より遥かに大きいため，その糸状のウェーブガイドを伝播する縦 波はほとんど分散性がないと言える. そのため, 光ファイバの接着点での超音波は，その波形を保ったまま分散 性の無い純粋な縦波として RFBG センサまで届く.

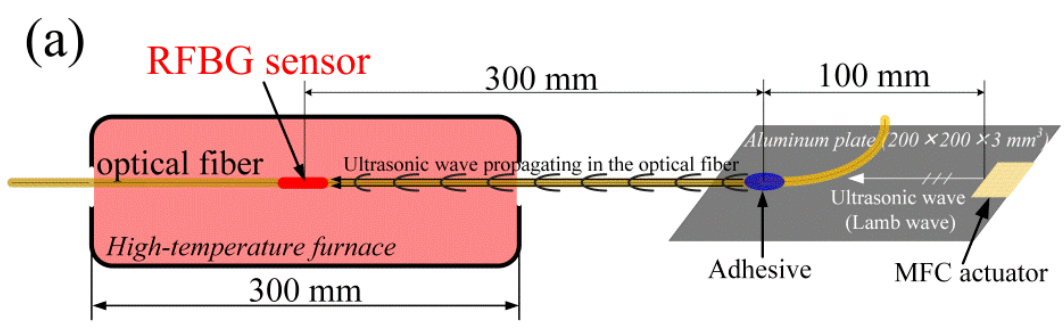

(b)

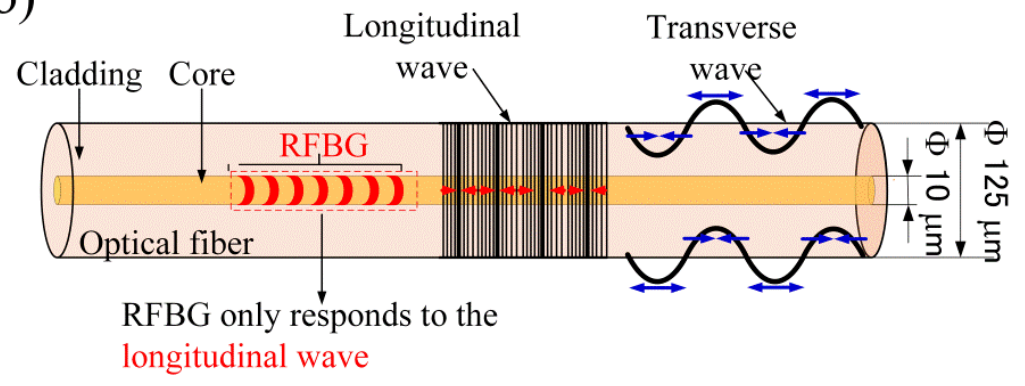

Fig. 4 (a) Experiment setup of ultrasonic wave detection using RFBG at high temperature. (b) Schematic diagram of ultrasonic-wave propagation in the optical fiber and the response of the RFBG to the waves. 
以上のような, 高温環境に適した超音波伝播システムを用いて, RFBG センサによる高温超音波計測を試みる. ここではまず，MFCアクチュエータへの入力信号に中心周波数が $300 \mathrm{kHz}, 600 \mathrm{kHz}, 900 \mathrm{kHz}$, 及び $1200 \mathrm{kHz}$ の 3 サイン周期バースト波を用いた。 それらの波形は，ファンクションジェネレータ（NF, WF1974）によって10 V の振幅電圧で発信し, さらに高速バイポーラ電源によって 10 倍に増大した.

そして，伝播波形を受信するため，RFBG 超音波センシングシステムを事前に調整する. 図 3 に示すように， 常温環境下では, RFBG のスベクトルにおける中央ピーク波長は $1550 \mathrm{~nm}$ 付近に位置しており, そのエッジの $3 \mathrm{~dB}$ （半值）レベルの波長にレーザの波長を合わせることで，システムを超音波計測が可能な状態にする．この常温 条件で受信した結果を図 5 に示す。この結果より，RFBG センサで超音波を計測できることが分かる.さらに， 各計測波形にフーリエ変換を施したところ, 入力超音波の中心周波数の増加に依存して, PSFBG センサの応答の 周波数分布も高周波数側へ移動している. よって，RFBG センサは広帯域にわたる超音波を計測可能であること が分かる．これは，UV により形成した $\pi$ の位相はアニーリング処理で異なる角度に変化しても，超音波による RFBG スベクトルのピークの波長シフトは，位相のズレの近傍でのひずみにより生じるためである. そのため, PSFBG から製作した RFBG センサは，元のPSFBG センサと同じく有効ゲージ長が極短であり，極めて優れた広 帯域性を有する.
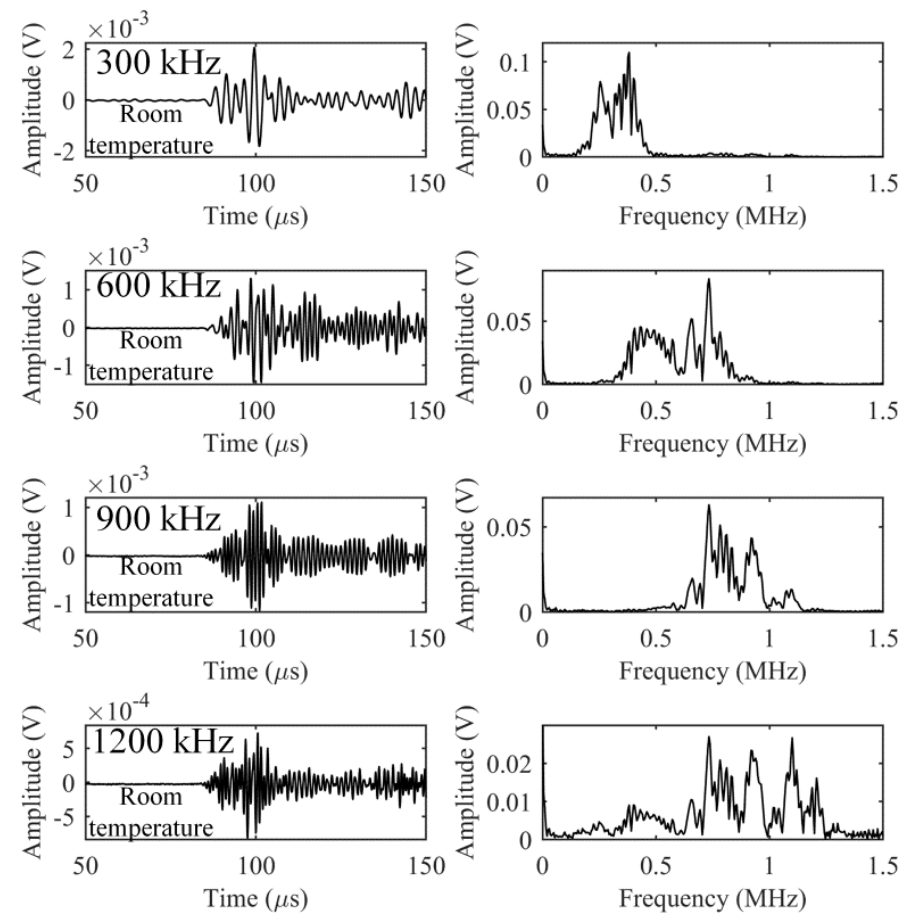

Fig. 5 Ultrasonic waves received by the RFBG sensor at room temperature and their Fourier transform results.

次に， $1000^{\circ} \mathrm{C}$ 高温環境下において同じ超音波計測を行う。ここでは，温度の上昇により， RFBG におけるピー ク波長は常温時の $1550 \mathrm{~nm}$ から $1564 \mathrm{~nm}$ までシフトした. 超音波計測が可能な状態を維持するため, レーザの波 長も 1564 近傍に調整した. 計測した超音波波形を図 6 に示寸. RFBG センサの優れた耐熱性を利用し，1000 ${ }^{\circ}$ の高温環境下でも超音波を計測することに成功した。ただし，図 5 と図 6 の計測波形を比較すると，同じ入力信 号に対して， $1000^{\circ} \mathrm{C} の$ 温度条件で計測した波形は，常温環境下で計測した波形より振幅が小さい。この振幅の変 化を定量的に評価するため, 常温環境下における各中心周波数での受信波形のピーク振幅に対する， $1000^{\circ} \mathrm{C}$ 温度 条件下における受信波形のピーク振幅の比を図 7 に示す. その結果, $1000^{\circ} \mathrm{C}$ での波形の振幅は-4.5 -6.5 dB まで減 少していることが確認できる。ここで, 図 1(b)と比べると, その減少の傾向は, 温度変化による RFBGの反射率 の変化とほぼ一致していることも確認できる. そのため, 温度の上昇により生じた RFBG の反射率の減少は, RFBG センサの感度に影響することが分かる.つまり, 有用性に優れる耐熱性超音波センサを構築するためには, そのセンサの高温環境下での耐久性も非常に重要であると考えられる，他の研究グループは，RFBG センサを高 
温環境に 9000 時間設置しても温度とひずみを計測できることを報告（Laffont et al., 2013a）しており，今後は， 高温超音波センサとしての耐久性を検証する必要がある.

ここで，図 5 と図 6 における，中心周波数が $300 \mathrm{kHz}$ の超音波入力に対応する計測波形とフーリエ変換結果を

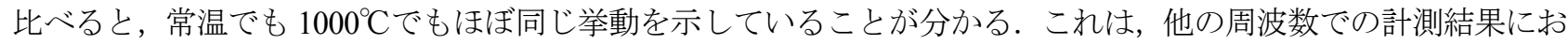
いてもいえる，以上の結果より，RFBG センサは，高温環境においても的確に超音波の波形を受信できることが 分かる. 超音波計測による非破壊検査では, 主に計測波形と周波数分布の変化から，損傷を検知・評価する. そ のため, RFBG センサの安定した計測特性は，高温環境での計測に非常に有効である.
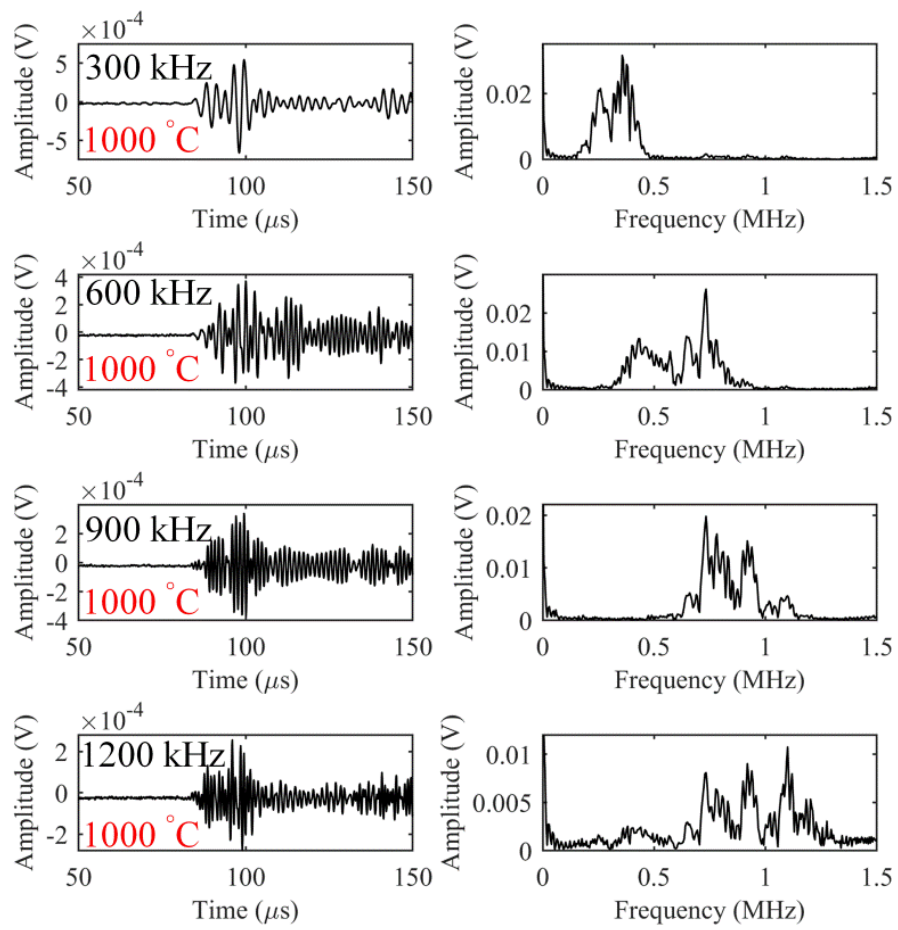

Fig. 6 Ultrasonic waves received by the RFBG sensor at $1000{ }^{\circ} \mathrm{C}$ and their Fourier transform results.

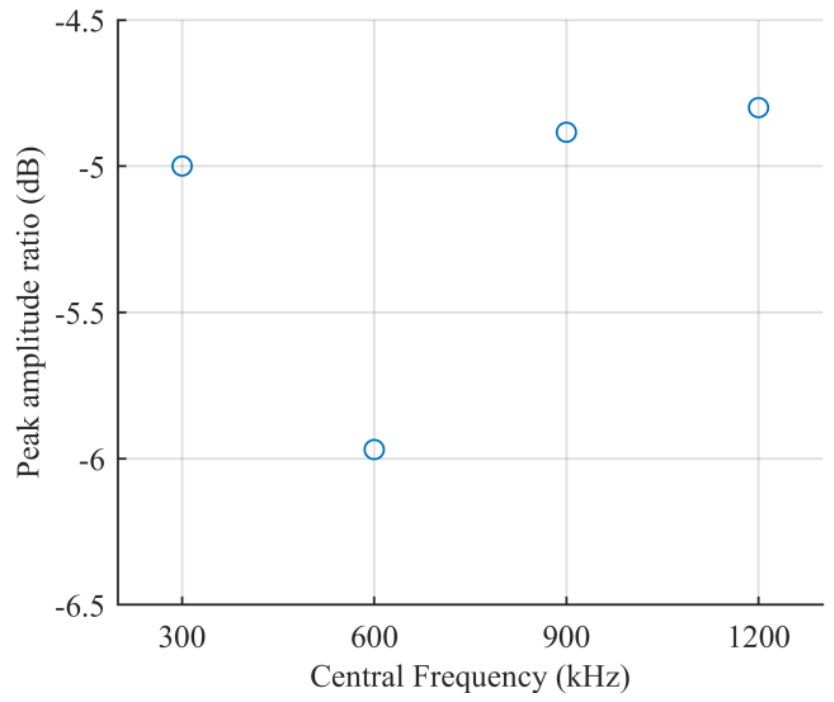

Fig. 7 Decrease of peak amplitude in the received waveform caused by temperature increase.

\section{4. 結言}


本研究では, RFBG センサの優れた耐熱性を利用し， $1000^{\circ} \mathrm{C} の$ 高温環境下でも超音波を計測することがで きた. しかも，PSFBGに対してアニーリング処理を行っているため，通常の FBG センサよりも，RFBG セ ンサの超音波に対する感度と周波数帯域が優れている.

今後，RFBG センサを用いて有効な超音波検査法を確立する際には，高温用超音波発振源に関しても検討しな ければならない，通常の超音波送受信に使用されている PZT 素子は, 高温用アクチュエータとして使用寸ること が難しい，一方で，非接触で超音波を励起可能なレーザ光源を発振側に用い，受信に RFBG センサを用いるとい う組み合わせで,アクティブな検査法に適用可能な高温用ガイド波送受信システムを構築することが考えられる. （井原, 2015）さらに，アニーリング処理とグレーティングの条件を工夫することで, RFBG センサの感度をさら に向上させた上で，損傷の発生に伴って生じる超音波，すなわちアコースティック・エミッション（AE）信号を 計測可能にすることも考えている. これらの能動的及び受動的非破壊検查法を確立することによって, 高温環境 下での CMC などの構造材料における内部損傷を有効に検知・評価することが期待できる.

\section{謝 辞 \\ 本研究は JSPS 科研費 JP15K06457 の助成を受けて実施した.}

\section{文献}

Bandyopadhyay, S., Canning, J., Biswas, P., Stevenson, M. and Dasgupta, K., A study of regenerated gratings produced in germanosilicate fibers by high temperature annealing, Optics Express, Vol.19, No.2 (2011), pp.1198-1206.

Bandyopadhyay, S., Canning, J., Stevenson, M. and Cook, K., Ultrahigh-temperature regenerated gratings in boron-codoped germanosilicate optical fiber using 193 nm, Optics Letters, Vol.33, No.16 (2008), pp.1917-1919.

Bueno, A., Kinet, D., Mégret, P. and Caucheteur, C., Fast thermal regeneration of fiber Bragg gratings, Optics Letters, Vol.38, No.20 (2013), pp.4178-4181.

Canning, J., Regeneration, regenerated gratings and composite glass properties: the implications for high temperature micro and nano milling and optical sensing, Measurement, Vol.79 (2016), pp.236-249.

Chen, R., Yan, A., Wang, Q. and Chen, K. P., Fiber-optic flow sensors for high-temperature environment operation up to $800^{\circ} \mathrm{C}$, Optics Letters, Vol.39, No.13 (2014), pp.3966-3969.

長秀雄, 伊藤寛明, 而熱型光ファイバセンサを用いた高温環境下での $\mathrm{AE}$ 計測 (特集 高温構造物・材料の超音波 非破壊検查法について), 非破壊検査, Vol.64, No.2 (2015), pp.62-66.

Daniel, C. B., Graham, T., Brian, C. and Wieslaw, J. S., Acousto-ultrasonic sensing using fiber Bragg gratings, Smart Materials and Structures, Vol.12, No.1 (2003), pp.122-128.

Fokine, M., Growth dynamics of chemical composition gratings in fluorine-doped silica optical fibers, Optics Letters, Vol.27, No.22 (2002), pp.1974-1976.

Hill, K. O., Fiber Bragg grating technology fundamentals and overview, Journal of lightwave technology, Vol.15, No.8 (1997), pp.1263-1276.

本庶誠, 赤坂伸宏, 而熱被覆ガラスファイバ, 特開平 6-148474 (1994).

井原郁夫，高温物体の超音波センシングとその展望 (特集 高温構造物・材料の超音波非破壊検查法について), 非 破壊検查, Vol.64, No.2 (2015), pp.48-55.

Jiang, X., Kim, K., Zhang, S., Johnson, J. and Salazar, G., High-temperature piezoelectric sensing, Sensors, Vol.14, No.1 (2013), pp.144-169.

Johnson, J. A., Kim, K., Zhang, S., Wu, D. and Jiang, X. High-temperature ( $\left.>1000^{\circ} \mathrm{C}\right)$ acoustic emission sensor, SPIE Smart Structures and Materials + Nondestructive Evaluation and Health Monitoring (2013), Paper No. 869428.

Kashyap, R., Fiber bragg gratings (1999), Academic press.

Kirk, K. J., Scheit, C. W. and Schmarje, N., High-temperature acoustic emission tests using lithium niobate piezocomposite transducers, Insight - Non-Destructive Testing and Condition Monitoring, Vol.49, No.3 (2007), pp.142-145. 
Laffont, G., Cotillard, R. and Ferdinand, P., 9000 hours-long high temperature annealing of regenerated fiber Bragg gratings, Fifth European Workshop on Optical Fibre Sensors (2013a), Paper No. 87941X.

Laffont, G., Cotillard, R. and Ferdinand, P., Multiplexed regenerated fiber Bragg gratings for high-temperature measurement, Measurement Science and Technology, Vol.24, No.9 (2013b), pp.094010.

Padture, N. P., Advanced structural ceramics in aerospace propulsion, Nat Mater, Vol.15, No.8 (2016), pp.804-809.

Rosenthal, A., Razansky, D. and Ntziachristos, V., High-sensitivity compact ultrasonic detector based on a pi-phase-shifted fiber Bragg grating, Optics Letters, Vol.36, No.10 (2011), pp.1833-1835.

Shao, L. Y., Canning, J., Wang, T., Cook, K. and Tam, H. Y., Viscosity of silica optical fibres characterized using regenerated gratings, Acta Materialia, Vol.61, No.16 (2013), pp.6071-6081.

Starodubov, D. S., Grubsky, V., Feinberg, J., Kobrin, B. and Juma, S., Bragg grating fabrication in germanosilicate fibers by use of near-UV light: a new pathway for refractive-index changes, Optics Letters, Vol.22, No.14 (1997), pp.1086-1088.

Wang, T., Shao, L.-Y., Canning, J. and Cook, K., Temperature and strain characterization of regenerated gratings, Optics Letters, Vol.38, No.3 (2013), pp.247-249.

Wu, Q. and Okabe, Y., High-sensitivity ultrasonic phase-shifted fiber Bragg grating balanced sensing system, Optics Express, Vol.20, No.27 (2012), pp.28353-28362.

Yang, H. Z., Qiao, X. G., Das, S. and Paul, M. C., Thermal regenerated grating operation at temperatures up to $1400^{\circ} \mathrm{C}$ using new class of multimaterial glass-based photosensitive fiber, Optics Letters, Vol.39, No.22 (2014), pp.6438-6441.

Yu, F., Okabe, Y., Wu, Q. and Shigeta, N., Fiber-optic sensor-based remote acoustic emission measurement of composites, Smart Materials and Structures, Vol.25, No.10 (2016), pp.105033.

Zhang, B. and Kahrizi, M., High-temperature resistance fiber Bragg grating temperature sensor fabrication, IEEE Sensors Journal, Vol.7, No.4 (2007), pp.586-591.

\section{References}

Bandyopadhyay, S., Canning, J., Biswas, P., Stevenson, M. and Dasgupta, K., A study of regenerated gratings produced in germanosilicate fibers by high temperature annealing, Optics Express, Vol.19, No.2 (2011), pp.1198-1206.

Bandyopadhyay, S., Canning, J., Stevenson, M. and Cook, K., Ultrahigh-temperature regenerated gratings in boron-codoped germanosilicate optical fiber using 193 nm, Optics Letters, Vol.33, No.16 (2008), pp.1917-1919.

Bueno, A., Kinet, D., Mégret, P. and Caucheteur, C., Fast thermal regeneration of fiber Bragg gratings, Optics Letters, Vol.38, No.20 (2013), pp.4178-4181.

Canning, J., Regeneration, regenerated gratings and composite glass properties: the implications for high temperature micro and nano milling and optical sensing, Measurement, Vol.79 (2016), pp.236-249.

Chen, R., Yan, A., Wang, Q. and Chen, K. P., Fiber-optic flow sensors for high-temperature environment operation up to $800^{\circ} \mathrm{C}$, Optics Letters, Vol.39, No.13 (2014), pp.3966-3969.

Cho, H. and Ito, H., Acoustic emission measurement at high temperature with an advanced AE monitoring system using heat-resistant optical fiber sensor, Journal of the Japancese Society for Non-destructive Inspection, Vol.64, No.2 (2015), pp.62-66 (in Japanese).

Daniel, C. B., Graham, T., Brian, C. and Wieslaw, J. S., Acousto-ultrasonic sensing using fiber Bragg gratings, Smart Materials and Structures, Vol.12, No.1 (2003), pp.122-128.

Fokine, M., Growth dynamics of chemical composition gratings in fluorine-doped silica optical fibers, Optics Letters, Vol.27, No.22 (2002), pp.1974-1976.

Hill, K. O., Fiber Bragg grating technology fundamentals and overview, Journal of lightwave technology, Vol.15, No.8 (1997), pp.1263-1276.

Honjyo, M. and Akasaka, N., Heat resistant coated glass fiber, Japanese patent disclosure H6-148474 (1994).

Ihara, I., Ultrasonic nondestructive sensing at elevated temperature and its prospective, Journal of the Japancese Society for Non-destructive Inspection, Vol.64, No.2 (2015), pp.48-55 (in Japanese). 
Jiang, X., Kim, K., Zhang, S., Johnson, J. and Salazar, G., High-temperature piezoelectric sensing, Sensors, Vol.14, No.1 (2013), pp.144-169.

Johnson, J. A., Kim, K., Zhang, S., Wu, D. and Jiang, X. High-temperature ( $\left.>1000^{\circ} \mathrm{C}\right)$ acoustic emission sensor, SPIE Smart Structures and Materials + Nondestructive Evaluation and Health Monitoring (2013), Paper No. 869428.

Kashyap, R., Fiber bragg gratings (1999), Academic press.

Kirk, K. J., Scheit, C. W. and Schmarje, N., High-temperature acoustic emission tests using lithium niobate piezocomposite transducers, Insight - Non-Destructive Testing and Condition Monitoring, Vol.49, No.3 (2007), pp.142-145.

Laffont, G., Cotillard, R. and Ferdinand, P., 9000 hours-long high temperature annealing of regenerated fiber Bragg gratings, Fifth European Workshop on Optical Fibre Sensors (2013a), Paper No. 87941X.

Laffont, G., Cotillard, R. and Ferdinand, P., Multiplexed regenerated fiber Bragg gratings for high-temperature measurement, Measurement Science and Technology, Vol.24, No.9 (2013b), pp.094010.

Padture, N. P., Advanced structural ceramics in aerospace propulsion, Nat Mater, Vol.15, No.8 (2016), pp.804-809.

Rosenthal, A., Razansky, D. and Ntziachristos, V., High-sensitivity compact ultrasonic detector based on a pi-phase-shifted fiber Bragg grating, Optics Letters, Vol.36, No.10 (2011), pp.1833-1835.

Shao, L. Y., Canning, J., Wang, T., Cook, K. and Tam, H. Y., Viscosity of silica optical fibres characterized using regenerated gratings, Acta Materialia, Vol.61, No.16 (2013), pp.6071-6081.

Starodubov, D. S., Grubsky, V., Feinberg, J., Kobrin, B. and Juma, S., Bragg grating fabrication in germanosilicate fibers by use of near-UV light: a new pathway for refractive-index changes, Optics Letters, Vol.22, No.14 (1997), pp.1086-1088.

Wang, T., Shao, L.-Y., Canning, J. and Cook, K., Temperature and strain characterization of regenerated gratings, Optics Letters, Vol.38, No.3 (2013), pp.247-249.

Wu, Q. and Okabe, Y., High-sensitivity ultrasonic phase-shifted fiber Bragg grating balanced sensing system, Optics Express, Vol.20, No.27 (2012), pp.28353-28362.

Yang, H. Z., Qiao, X. G., Das, S. and Paul, M. C., Thermal regenerated grating operation at temperatures up to $1400^{\circ} \mathrm{C}$ using new class of multimaterial glass-based photosensitive fiber, Optics Letters, Vol.39, No.22 (2014), pp.6438-6441.

Yu, F., Okabe, Y., Wu, Q. and Shigeta, N., Fiber-optic sensor-based remote acoustic emission measurement of composites, Smart Materials and Structures, Vol.25, No.10 (2016), pp.105033.

Zhang, B. and Kahrizi, M., High-temperature resistance fiber Bragg grating temperature sensor fabrication, IEEE Sensors Journal, Vol.7, No.4 (2007), pp.586-591. 